\title{
DIFFICULTIES IN PROVING FORGERY
}

\section{Albert S. Osborn $†$}

Measured by the amount in controversy, certain cases in which forgery is alleged are among the most important matters in litigation in American courts. One or more of these cases, in which thousands, hundreds of thousands, and even millions of dollars are being contended for, is in progress on nearly every court day. These cases are mainly claims against estates and corporations in the form of wills, notes, agreements or contracts. When a claim is based on a forged document there are special difficulties involved in the proof of the facts. Some of these difficulties cannot be avoided but, with advance knowledge, they can sometimes be prepared for and, in some measure, counteracted. Unprepared attorneys learn of them for the first time in the midst of a trial. When all of the hindrances and obstructions surrounding the proof that a forged document is in fact a forgery, are enumerated, it is somewhat surprising when the undertaking is successful, especially if proof must, to any considerable extent, be based upon the qualities of the forged document itself. Some of these difficulties are:

(I) Positive supporting perjury by co-conspirators; (2) Definite and detailed perjury by relatives and friendly witnesses actuated by sympathy and friendship; (3) Restrictive legal rules still in force in certain states regarding handwriting and document expert testimony; (4) Objections and arguments by an alert attorney, whose aim is to prevent proof, who quotes the old critical pronouncements which were the direct outgrowth of the ancient laws excluding standards of comparison, reasons for opinions, and the use of enlarged photographs and all optical instruments; (5) Unconscious prejudice in the minds of many of the older attorneys and judges, based on the overruled decisions still printed in the books; (6) Lack of scientific training and technical knowledge of the subject of forgery by attorneys and judges; (7) Inexperience and lack of technical ability of local technical witnesses in certain cases who are called to prove that a document is not genuine; (8) The employment by the claimant, or rather the claimant's attorney, of unworthy specialists as witnesses who take a case no matter what the facts may be; (9) Incompetent jurors who cannot be technically educated during one trial; (Io) Prejudice against the general subject of expert testimony, based mainly upon abuses, especially in sensational murder cases, of medical and insanity expert testimony; (II) The law allowing brief, unwitnessed, holographic wills to be probated, and in Pennsylvania allowing brief, unwitnessed, undated wills to be probated on proof of the

$\dagger$ Expert in the examination of documents, New York City; author of QuESTIONED Documents (2d ed. 1929); The Problem of Proof (I922). 
signature only. (12) Another serious difficulty arises when the genuine signatures of a decedent, whose signature has been forged, are of a hesitating, tremulous, decrepit and unskilful character and easy to imitate. Under these conditions it often is difficult to prove that an actual forgery is a forgery. In cases of this kind a forgery may, of course, be too skilfully written or the imitation of tremor and weakness may be much overdone. It is true, however, that the character and poor quality of the writing imitated may be another serious difficulty in proving forgery. Some of the most obvious and unmistakable forgeries, however, are the ones most strenuously defended. ( 13 ) The final and not the least important difficulty is the contingent fee contract in important claim cases, which makes an attorney in effect a party financially interested to the extent of thirty, forty or even fifty per cent. of a possible recovery, in some cases, of many thousands of dollars.

The forgery cases hard to prove are not those involving the thousands of insignificant forged documents in the form of checks and drafts cashed every year in this country. These forgeries often are on fictitious accounts, and the active operators occasionally are caught "red-handed" and then are easily convicted on the surrounding circumstances alone. Yesterday and today and tomorrow in this land of opportunity these fraudulent documents will be paid. One of the largest surety companies states that forgery is one of the most profitable crimes in America and reports that from twenty to fifty million dollars are paid every year on forged documents. In most instances these forgeries call for comparatively small amounts and usually after discovery of the forgery there is no trace of the forger who, after his success, departs for other fields, usually not far away.

These men, who are in fact "professional forgers", are, however, almost without exception finally apprehended and convicted. They become so careless, on account of the ease with which these forged instruments can be cashed, that they are led into serious errors. With many of them forgery becomes an uncontrollable habit. They are convicted again and again under different names and in different places and serve short sentences. One man recently went to Sing Sing who had spent thirty of the seventy-two years of his life in prison for forgery, and finally, as the result of a last desperate attempt, the old and broken man went "up the river" probably for the last time.

The class of forgeries referred to above as difficult to attack successfully are, as a rule, undertakings of a more ambitious character, sometimes calling for amounts even up to millions of dollars; they are not cashed over a bank counter but in a court of law. These important raids many times are skilfully planned and often are successful. The legal rules, the procedure, and the prejudice in many courts favor these claimants and their legal 
assistants. In many cities successful claim case attorneys are waiting, in their mahogany furnished offices, ready and able to assist in the profitable venture of cashing a major forgery on a contingent fee contract; they know just what is necessary.

Like innocence in a defendant, genuineness in a document is assumed, especially in a formal document, with seals, witnesses, silk tape and a blue cover, all concocted to fit certain specific conditions in the life of a decedent. These fraudulent cases are sometimes presented in court by a conscientious attorney who, at the outset at least, believes the story of those who come to him with the claim. Here and there attorneys withdraw in the midst of a trial of these cases when the character of the claim document is clearly shown, but this act is unusual and is even condemned by many members of the legal profession. "Follow the case through," they say, "even if it goes into hell."

The most serious difficulty in the proof of forgery in these important cases is that first enumerated above, that is, supporting perjury by coconspirators and friendly witnesses. ${ }^{1}$ It appears clearly that it is not diffcult to convince certain friends or acquaintances that any document is genuine, when the undertaking is surrounded by sympathy and perhaps grows out of conditions that, in some measure at least, seem to justify the claim. There are friendly witnesses who testify positively in these cases without considering it actual perjury to stretch the truth in order to assist in securing for a claimant what it is thought the claimant is entitled to receive. These perjurors do not fear punishment for the act either in this world or the world to come. Some of these witnesses will testify for a friend in this way when they would not testify in their own behalf regarding a fraudulent claim. The typical attitude of these witnesses, who have taken an oath to tell the truth, is: "I do not care how the disputed document looks; Mary ought to have the money."

${ }^{2}$ See In re Nelson's Estate, I9I Cal. 280, 216 Pac. 368 (I923). Expert witnesses having testified that in their opinion the will was not in the handwriting of the deceased, such testimony was amply sufficient to sustain the verdict of the jury, notwithstanding the fact that the acquaintances of the decedent familiar with his handwriting testified that in their opinion the entire document was in the handwriting of the decedent.

In Matter of Glazer, N. Y. L. J., April I2, 1934, at 1763 , I764, Surrogate Wingate said: "As a result of the appearance and demeanor of the subscribing witnesses upon the stand, there is no escape from the conviction that they have deliberately, intentionally and probably concertedly endeavored to minimize everything pointing to the seriousness of the patient's illness and magnified every contrary circumstance to the point of distortion. They have colored their testimony until it is substantially unbelievable."

"Judges, lawyers, police authorities, investigators and the general public, are all convinced that perjury is wide spread. Justice Joseph W. Keller, of the City Court of New York, in concluding with 'perjury is a greater menace to the administration of justice than congested calendars or any other cause', indicates the necessity for striking at the prevalence of perjury if any feasible method can be found. . . . On many the oath has no binding effect. It is considered merely a tiresome formality, and the manner in which it is administered in many courts does much to create this impression." - Charles $K$. Burdick, in THE PANEL, January-February, 1934. 
In one important will case six of these "friends of the claimant" testified that they saw a will signed; yet, after the fraudulent character of the document was shown, a jury decided that the will was a forgery. ${ }^{2}$ In some states this verdict would at once have been set aside by a "higher" court on the ground that it was "against the weight of evidence", but only one judge so voted in the appellate court. This judge followed the ancient rules and precedents in a case in which the fact of forgery was so evident that it could almost be shown to a child.

It is to be expected that alleged witnesses to a forged document will be brought forward who remember the most unimportant details of an event which occurred long before. The exact time, place and circumstances are all described and, what is stranger still, often are described in just the same manner by more than one witness. Who spoke first, just who were there, where they sat, and just what was said, are all related in the utmost detail, although the occurrence in some instances took place years before. The weakness of some testimony is that it is too good.

Co-conspirators in these cases will of course testify in the most effective way that their ingenuity, or that of their experienced attorney, can devise. Some corrupt witnesses are effectively protected and their testimony is accentuated by careful advance planning which partly justifies the contention that they are disinterested witnesses. Testimony of this kind is of course very formidable.

In the argument of the claimant's attorney, as well as in the law books and judges' charges, all of this testimony by alleged eye-witnesses, no matter how suspicious or false it may be, is referred to as "the fact testimony" in the case, as compared with the "mere opinion expert testimony" in the same case. This disparaging distinction is often made no matter how effectively this expert testimony shows the fraudulent character of the document. ${ }^{3}$

${ }^{9}$ People v. Storrs, 207 N. Y. I47, I00 N. E. 730 (I912). The decision was reversed on another ground. See Baird v. Shaffer, Ior Kan. 585, 587, I68 Pac. 836 (I9I7), where the court said: "The testimony of attesting witnesses to a will may be overcome by any competent evidence . . . expert and opinion evidence is just as competent as any other evidence. Indeed, where the signature to a will is a forgery, and where the attesting witnesses have the hardihood to commit perjury, it is difficult to see how the bogus will can be overthrown except by expert and competent opinion evidence. . . . The rule contended for by appellants would frequently baffle justice and give judicial countenance to many a high-handed fraud."

3 "They testified, in substance, that the decedent's signature on the register was not written by him, according to their opinion. They referred to no fact nor pointed out any reasons for their statements and left their flatly stated opinions unaided by the statement of any fact to enable either the court or the jury to draw a legal conclusion as to the accuracy of their testimony, or its probative effect. - . . Their misfortune in that respect may not be urged against their honesty, but no doubt it should be considered in weighing their testimony, on the controverted fact under consideration." Pioneer Coal Co. v. Polly, $208 \mathrm{Ky} .548,555,27 \mathrm{I}$ S. W. 592, 594 (I925).

See In re Creger's Estate, I35 Okla. 77, 82, 274 Pac. 30, 35 (I929), where the court said: "In the notable case of Baird v. Shaffer, supra, from a Supreme Court of Kansas, which we have cited on another point, a bold forgery of a will was prevented from taking its intended spoils by giving due and proper credit to expert and opinion evidence in regard 
One of these two classes of testimony is manifestly addressed to the credulity of the hearer, while the other class is addressed to the judgment, the scientific knowledge and experience of the hearer. Some courts have gone so far as to say, one as recently as $1929,{ }^{4}$ that in no case where witnesses testify they saw a document signed should a decision against the document be based upon any kind of expert testimony. In effect they say this should be the rule no matter how logical, reasonable and conclusive the testimony may be. This I929 decision was, of course, a complete surrender to credulity and prejudice.

There still are mature judges here and there in trial courts who will not permit effective and convincing handwriting expert testimony to be given; they will not permit forgery to be proved. It is unfortunate, as well as unjust, when this prejudice vents itself in the form of unjustified criticisms of capable and conscientious special witnesses who are endeavoring to assist in promoting justice. The interests of justice certainly are safeguarded when the judicial office is occupied by one who is fair, fearless and unprejudiced-that is, when he is permitted to take any considerable part in the trial of a lawsuit.

In courts where the prejudiced and critical view of expert testimony controls, it naturally is very difficult, if not impossible, to prove forgery in important cases. In courts of this class hundreds of good cases are not tried because of the hopeless prospect. The courts of certain states have long maintained this critical attitude, although nominally decisions now say in some of these states that all testimony must be considered for what it is worth. The old prejudice still has its effect, however, as shown by the r 929

to the genuineness of handwriting. But this expert and opinion evidence must always bear the qualifications given it as a result of recent scientific investigation, . . "

For decisions in a similar vein see Sloan v. Maxwell, 3 N. J. Eq. 563 (183I); Gordon's Case, 50 N. J. Eq. 397, 26 Atl. 268 (1892) ; Wright v. Flynn, 69 N. J. Eq. 753, 6r Atl. 973 (I905).

“In re Harris' Estate, 247 Mich. 690, 696-697, 226 N. W. 661, 663 (1929). "To permit an expert witness in a case of contested handwriting to directly answer the question as to the genuineness of the signature in dispute is to permit him to invade the province of the jury,to answer the very question which it is the duty of the jury to answer. . . The opinions of experts are of no weight when contrary to sworn testimony as to facts."

In a retrial of the case a will was declared a forgery by a jury verdict based on handwriting expert testimony, but the judge, following literally and exactly the I929 decision, set the verdict aside. When this case was appealed the Supreme Court reversed its own finding of 1929 in the same case and agreed with the jury. The I 929 decision no doubt grew out of prejudice resulting from the old critical Michigan decisions. The Ig29 opinion actually quotes as a justifying precedent an old English opinion decided nearly a hundred years before. It should be remembered that it was only nineteen years ago that genuine writings as standards of comparison were first admitted in Michigan courts. There are many judges who never tried an important handwriting case with real standards and under modern rules.

For illustrations of the application of the old rules see Matter of Foster's Will, 34 Mich. 2I (I876); Borland v. Walrath, 33 Iowa I30 (I87I). In the latter case the court, at I33, said: "It must be confessed, however, that it [handwriting comparison] is of the lowest order of evidence, or of the most unsatisfactory character. It cannot be claimed that it ought to overthrow positive and direct evidence of credible witnesses who testify from their personal knowledge." 
Michigan opinion. The law in the state of California, as in numerous other states, formerly required a judge to charge the jury, if requested to do so, that handwriting expert testimony was of a low order and "should be received with great caution", and as a result was of course under suspicion. In many cases this charge rendered the testimony attacking a document practically valueless and prevented proof of forgery. ${ }^{5}$

A genuine document may prove itself by its own inherent and undeniable qualities of genuineness, but this is not true of a forged document. Forgery must always be supported by perjury. Perjury of all kinds and degrees is so common and expected in courts of law that it attracts but little attention. It is taken as a matter of course, and this is especially true in connection with forgery cases. The oath has little, if any, restraining effect, especially as unimpressively administered, and lawyers and judges, with no especial concern, seem to consider that perjury is a regular part of legal proceedings. Half of the testimony in certain cases is perjury.

The inevitableness of perjury in forgery cases is well understood and this is especially true of cases of importance. This condition is no doubt partly due to the fact that few perjurors are ever prosecuted. As a rule an unsuccessful claimant, who bases a claim on a crude forged document, is not prosecuted but goes his way, or perhaps more often her way, undisturbed. If a burglar attempts to break into a house and is caught in the act on a ladder, he is prosecuted and sent to jail, but one can attempt to "break into" a million dollar estate and escape prosecution, excepting in rare instances.

5 'Is it not a fact that the letter ' $r$ ', as it appears in this word to have been changed into an ' $n$ ', strong evidence that the letter ' $F$ ' has been changed by striking out the cross to the letter ' $\mathrm{T}$ '? . - . An objection to this question was made by plaintiff and sustained. . . . We perceive no error in this ruling. . . . It was the province of the court trying the facts to make all inferences from the facts in evidence." Kruse v. Chester, 66 Cal. 353, 355, 5 Pac. $6 \mathrm{I}_{3}, 6 \mathrm{I}_{4}$ ( 1885 ).

This ruling in this case on the specific, detailed point described was no doubt correct, but the comment following, referring also, it clearly appears, to this particular inquiry, has been widened and extended, by certain trial attorneys and an occasional judge, to mean that an expert witness can make no comment or interpretation of any kind whatever on the facts pointed out and express no reasoning as to their significance or bearing on the question regarding which he is asked to give his reasons for an opinion. In People v. Bird, 124 Cal. 32, 56 Pac. 639 ( 1899 ), an objection no doubt based on the Kruse case, as well as Grigsby v. Clear Lake Water Co., 40 Cal. 396 (1870), was overruled. The contention was that the testimony was "argumentative".

The following decisions show the progress of the California courts: Grigsby v. Clear Lake Water Co., supra at 405: "Such evidence should be received with great caution by the jury. . . "Estate of Nelson, supra note I, at 283, 216 Pac. at 369: "Appellant contends that the trial court erred in refusing an instruction to the effect that the testimony of expert witnesses [as to handwriting] should be received with great caution. This instruction was properly refused." Hirshfeld v. Dana, I93 Cal. I42, I55, I65, 223 Pac. 45I, 456, 460 (I924): "It is the duty of the jury to consider and weigh the opinions of the experts with the other evidence in the case and then determine upon all of the evidence where the truth lies. . . But it is never proper to instruct the jury that expert testimony is or is not reliable or as to how the jury should appraise it."

Fifty-three years was sufficient time for the California Supreme Court to reverse the old rule, but more than fifty years are required in some states. It will be seen by the Ig24 decision, however, that appellants "hark back" to the old restrictive decision, hoping perhaps that the court will forget that they have overruled the old theory. 
In a great majority of cases nobody is prosecuted and nobody is even criticised. It is not improbable that those similarly inclined are encouraged to make a similar attempt, with the procedure improved and the errors perhaps corrected that rendered the other undertaking unsuccessful. ${ }^{6}$

Next to perjury as a difficulty in proving forgery, the main influence protecting forgers is that growing out of the old decisions, annotations and textbook criticisms and discussions which attack technical testimony regarding proof of documents and handwriting. These rules were the direct outcome of the old legal limitations that were developed in an illiterate and unscientific age. Part of the efficient work of the attorney against the facts consists in getting before a jury and into current newspaper reports a reflection of these old criticisms. Paragraphs and even editorials are thus inspired and are written by those who do not know the origin of the criticisms and of course do not know that they are thus aiding forgers.

One of the most common and most unjust criticisms is that a conflict in testimony warrants a condemnation of all the testimony, good and bad. This may be true of only opinions but is not true of reasoned and illustrated testimony. The attorney against the facts often purposely brings about a conflict in the testimony in order that he may make this unjust argument, thus slurring his own witness. Many textbooks and digests still quote the old outlawed, critical stuff and it has its effect. In contrast with this unscientific view, Professor Wigmore discusses the subject in a sane and scientific manner and wisely says that expert testimony regarding handwriting should be measured by its convincingness, and this is the growing attitude regarding the subject in progressive courts in many states. ${ }^{7}$

By reason of the old prejudice it has been necessary for supreme courts to say, over and over again, "If document expert testimony is convincing it should be allowed to convince." Medical and other scientific books do not print and reprint the errors of the past, but a young lawyer who buys the "reports" buys all the errors as well as the correct matter. If one even now takes the reports and digests and annotations on this subject and follows them back through only a few years, it is easy to reach the conclusion that testimony regarding forgery is weak and unreliable and perhaps should not be permitted in any court. ${ }^{8}$ An example appears in a recent digest of the

- Two notable and encouraging exceptions have recently occurred in the City of New York. At the close of the civil action in the $\$ 30,000,000$ Wendel case the matter was sent to the District Attorney by Surrogate Foley, and the claimant is now serving a prison sentence. In the $\$ 4,000,000$ Ridley Estate case, just ended, the matter has also been sent to the District Attorney by the same judge, and the claimant in this case, if convicted, faces similar punishment. In the Borough of Brooklyn, New York City, an important fraudulent will was recently declared void. After the most positive preliminary perjury, facts were discovered which led to a withdrawal of the will, the latter concerning an estate of several millions of dollars. No action of any kind was taken against the fraudulent claimants.

'See I WIGMIORE, EVIDENCE (2d ed. I923) §§ 693-709.

- The following citations from various states show the now almost unbelievable rulings of the past. They are still in the books, however, and even now indirectly affect judgments 
law in the great state of California. This digest quotes first a forty-nineyear-old opinion, Kruse $v$. Chester, ${ }^{9}$ as if it should be the first to be considered, despite the fact that the courts of that state have said repeatedly that expert testimony on the subject should be considered for what it is worth, as in the case of any other testimony. If the old digest opinion is followed literally it makes a witness a dumb witness who simply points to what he sees, with no interpretation. It is easy to understand how the old opinions are praised and emphasized by the claimant's attorney, whose case must be won against expert testimony. The old opinions are cited when it is known that they have been overruled. Some of these later progressive opinions are cited below. ${ }^{10}$

The steps in the progress from the ancient rules are substantially as follows :

First, no handwriting comparison was allowed by witnesses or jury. This rule was no doubt due, in part at least, to the illiteracy of jurors in

on the subjects discussed. See People v. Frowley, I85 Ill. App. 338 (I9I4) (comparison of writing not allowed); Bowen v. Jones, I3 Ind. App. 193, $4 \mathrm{I}$ N. E. 400 (I895); Tome v. Parkersburg Branch R. R., 39 Md. 36 (1873) (expert comparison of handwriting entirely excluded) ; Vinton v. Peck, I4 Mich. 287 (I866) ; Taylor Will Case, to Abb. Pr. (N. s.) 300 (N. Y. I87I) (testimony from photographs of handwriting excluded); Hynes v. McDermott, $82 \mathrm{~N}$. Y. 4I (1880) (expert not allowed to use magnifying glass); Hanley v. Gandy, 28 Tex. 2II (I866) (comparison of handwriting refused since "controversy will likely arise on collateral issues") ; Campbell v. Campbell, 2r5 S. W. I34 (Tex. Civ. App. 1919).

"The test of genuineness ought to be the resemblance, not to the formation of the letters in some other specimen or specimens, but to the general character of the writing, which is impressed on it as the involuntary and unconscious result of constitution, habit or other permanent cause, and is, therefore, itself permanent. . . U Upon these grounds directly, as I conceive, although not on these alone, our law has not, during a long course of years, permitted handwriting to be proved by the immediate comparison by a witness, of the paper in dispute with some other specimen proved to have been written by the supposed writer of the first." Doe d. Mudd v. Suckermore, 5 A. \& E. 703, 705-706 (I835). This was the illogical argument against the admission of genuine writing for comparison that was cited hundreds of times in English and American opinions. The argument in effect was that an uninterested glance was a better method of learning about a thing than to study it carefully. This is a forceful illustration of the legal unscientific mind. This unscientific English rule was folJowed by American courts, excepting those of Massachusetts and Connecticut. The federal courts did not change the practice until I9r3 and the change in Texas was not made until x933. England changed the rule by statute in I854. See infra note II.

${ }^{9}$ Sipra note 5 .

${ }^{10}$ Venuto v. Lizzo, 148 App. Div. I64, 167, 132 N. Y. Supp. I066, I068 (IgII). "The conclusion of a handwriting expert as to the genuineness of a signature, standing alone, would be of little or no value, but supported by sufficiently cogent reasons his testimony might amount almost to a demonstration. While the court in this case did not directly refuse to allow the experts to state their reasons, as was done in the case of Johnson Service Co. v. MacLernon, I42 App. Div. 677, the effect of allowing constant trivial objections and of the erroneous rulings was virtually equivalent to such denial."

See further, Ausmus and Moon v. People, 47 Colo. 167, 107 Pac. 204 (19ro) ; Boyd v. Gosser, 78 Fla. 64, 82 So. 758 (I918) ; Fekete v. Fekete, 323 I11. 468, 154 N. E. 209 (I926); Dickenson v. Inhabitants of Fitchburg, 79 Mass. 546 (I859) (Massachusetts, together with Connecticut, never entertained the old view); Wakeley v. State, II8 Neb. 346, $225 \mathrm{~N}$. W. 42 (I929); Matter of Burtis, 43 Misc. 437,89 N. Y. Supp. 44I (I904); McKay v. Lasher, I2I N. Y. 477, 24 N. E. 7 II (I890); Richards v. Huff, I04 Okla. 221, 23I Pac. 76 (I924); Henry's Estate, $276 \mathrm{~Pa}$. 5II, I20 Atl. 454 (I923). It is interesting to note that as early as I820 it was said: ". . . the mere opinions of witnesses are entitled to little or no regard unless they are supported by good reasons." Harrison v. Rowan, 3 Wash. 580 (C. C. N. J. I820). 
many parts of England. Next, comparison of writing was haltingly allowed with writing "in the case for some other purpose". Then in England in 1854 came the statute allowing writings to be admitted for purposes of comparison. ${ }^{11}$ The Ohio Supreme Court in I850, following Massachusetts and Connecticut, had adopted the new rule, and the New York statute was adopted in $1880,{ }^{12}$ while the Pennsylvania statute was adopted in $1895 .{ }^{13}$ The whole subject was, however, clouded by the ancient restrictions and the testimony was often weakened, if not wholly nullified, by court criticisms to the effect that the testimony was admissible but dangerous. This attitude continues in certain courts down to date.

At first only opinions were given, but gradually the practice was adopted that allowed a witness to give the reasons for his opinion that a writing was genuine or a forgery. The extent to which this is allowable is still being fought in certain courts, although in New York, Pennsylvania, Virginia, Illinois, Florida, Kansas, Nebraska, and the leading states generally, the witness is permitted to give his opinion, the reasons and the reasoning which is the basis for the opinion. This is, of course, the last and most important step in this kind of proof and not only enforces correct testimony but exposes incorrect testimony to justified criticism and attack. Numerous decisions now say plainly that if no reasons are given, or no good reasons, the testimony deserves no consideration. The opinions cited herewith discuss these various points. ${ }^{14}$

Lack of scientific knowledge and technical training of lawyers and judges, let it be plainly said, is another serious handicap in proving forgery. The technical proof that a document is a forgery is, of course, a scientific proceeding and a serious difficulty in making this proof is the fact that many lawyers and judges are not scientifically minded. Even the lawyer who represents the worthy contestant in some cases remains practically ignorant of the subject throughout the trial. There are books on the subject but this lawyer does not even know their names. Document expert testimony in cases of this kind, especially against well-planned and unblushing perjury, is often unsuccessful, mainly because the trial attorney is not qualified to try the case. Under his unskilled leadership the testimony is not presented in the proper order and with the proper tone and emphasis. This is a difficulty that could be removed but it often remains to the end. Many trials are very far from being scientific performances and the outcome is the logical result of the methods employed. Even a skilled witness is unable to present

II I7 \& I8 VICT. c. 125 (I854).

10 N. Y. Civil PRACTICE ACT (1920) § 332.

13 Pa. Stat. Ann. (Purdon, 1930) tit. 28, § I62.

is See Henry's Estate, $276 \mathrm{~Pa}$. 5I, 5I4, I20 Atl. 454, 455 (I923), where the court said: "It may not be amiss to add that the weight of opinion evidence on a question of handwriting depends on the cogency of the reasons given; here they do not appeal to us as convincing." 
convincing expert testimony without the assistance of a qualified attorney who is prepared to ask the proper questions.

In some instances trial counsel in these cases are themselves not only uninformed, but prejudiced on the subject and know but little more about the case after they are defeated. They cannot, of course, make the proper, immediate, vital arguments in answer to objections during the presentation of the case and are almost wholly disqualified when it becomes necessary to make a convincing argument at the close of the trial. Unqualified counsel of this kind often spoil even the testimony of their own witnesses by persistently putting in the evidence in their own bungling and ineffective manner. Unlike the medical profession, there unfortunately is no such thing in the law as malpractice. ${ }^{15}$

It is of course difficult, if not impossible, to prove forgery by the testimony of incompetent witnesses. In many localities there is no special witness qualified to testify effectively on the technical subject of forgery, especially in connection with difficult cases involving clever forgeries. In many instances bank clerks and bookkeepers are asked to look at writing of this kind for a few minutes and then, without further study or preparation, are asked to give positive testimony which in many instances is not correct and in most cases is not convincing. ${ }^{16}$ In some of the old opinions this offhand testimony, as well as the testimony of the witness who has actually seen the party write, perhaps once, is emphasized and glorified as being particularly important. It would be better many times, with an uninformed judge, unin-

15 "While many of the criticisms of expert testimony as it exists are groundless, there is still just cause for complaint, the responsibility for which rests upon the legal profession. The remedies lie in higher standards of professional ability and practice in respect to this subject, in the recognition of the necessity of a knowledge of it for a legal education, and in the requirement of such knowledge for admission to practice." Lindsey, The Law of Expert Testimony and the Proposed Changes Therein (I902) 59 LEGAL INTELLIGENCER 474, 475.

"The lawyer who introduces the expert is sometimes at fault. He overlooks the most impressive thing. He seems to think that the main purpose of the qualifying evidence is to satisfy the judge that the witness should be allowed to testify as an expert. Where this conception is held by counsel a great deal of the force of such testimony is lost. The main psychological purpose of the evidence which qualifies the expert is not to show that he is competent to testify. This is, of course, a necessary purpose; but it is only a secondary one in importance. The main purpose is to lay a foundation for the evidence which follows. . . . The necessary time must be taken not only to qualify the witness as an expert but to show the value of expert testimony. Unless the position of the expert is definitely established at the beginning it might just as well not be established at all." BROWN, LEGAL Psychology (I926) II3.

${ }^{18}$ See Succession of White, 132 La. 890, 902, 6I So. 860, 864 (I9II), where the court said: "As to the expert evidence, we do not consider paying tellers of banks as experts in handwriting. Such officials, doubtless, have a certain skill in the comparison of signatures on bank paper, but cannot be considered as experts in chirography. . . . In cases of this kind the work of an expert is of assistance to the court, in pointing out differences and discrepancies in handwriting, which afford the judge a basis for forming his own opinion as to the genuineness of the handwriting in question." See further, In re Varney, 22 F. (2d) 230, 237 (1927); Magnuson v. State, I87 Wis. I22, 135, 203 N. W. 749, 754 (1925).

"Whether one could obtain a sufficient notion of the general character of a person's hand by seeing him write once only might well have been doubted. Tradition, however, has handed down a fixed rule that seeing a person write once only is as a matter of law sufficient." I WIGMORE, Evidence (2d ed. 1923) §694. 
formed counsel and an uninformed jury, to try cases of this kind on the general surrounding conditions and facts alone rather than upon any consideration whatever of the technical questions by those who are not qualified. It must be remembered also that there is present the attorney against the fact who, in order to win, must prevent proof. He constantly utilizes and emphasizes all of the difficulties that make proof of forgery difficult.

There is also the corrupt witness, mainly developed by the contingent fee advocate, who appears for anyone with the necessary price and defends any forged document. When only bare opinions were required these corrupt witnesses brought about a direct conflict in the testimony and often aided the desperate attorney and his unworthy client. Now, however, in many courts these witnesses must give reasons for their opinions and their aid is not so valuable as in former days. If their reasons are not reasonable they are given no attention.

Another serious stumbling block in the path of technical proof is the ordinary jury. It is of course true that no matter how thoroughly a case may have been prepared and how correctly presented, the verdict may be against the facts if the decision is made by unqualified jurors. In many states, as in New Jersey and numerous other states at the present time, the principal weakness in the administration of justice is in the poor quality of the jury. Untrained and inexperienced men and women of all classes, kinds and qualities are selected to decide difficult questions presented to them by disagreeing witnesses and disagreeing attorneys. Some juries, of course, should be censured for improper verdicts on good testimony, but the primary faults usually are in the methods of selecting the jurors and in the court procedure, especially in those courts where judges have no power. In many states a judge must sit silent and see justice defeated. In these cases justice is not only blind, but also deaf and dumb.

Of course, if a jury is stupid it does not much matter how the facts are presented; the decision will be based on something other than the evidence. Forgery cases in other nations than the United States of America are not tried by juries, but in this country difficult questions of forgery, of science, of art and mechanics are in many courts now presented for decision to those who manifestly are not qualified to do what they are asked to do. In Oklahoma certain civil cases have been presented to a judge and to associates selected from the members of the bar with most gratifying results.

When one considers the importance and majesty of the law, with human rights, property and liberty within its control, with the great marble courthouses and the noted law schools, great law libraries, and the enormous expense involved, it is pitiful to think that finally important litigated questions must be submitted for ultimate decision to unqualified jurors who should not have been selected for this important duty. It is discouraging to think 
that this condition must continue year after year. Does it not seem that something could be done to bring about improvement if lawyers really wanted improvement?

Expert testimony to the average layman and most lawyers, as featured in reports of sensational lawsuits, is that relating to medicine or insanity. There has been and still continues to be great abuse of expert testimony on these subjects and there is ample basis for criticism. In these cases the testimony is almost entirely mere opinion on a subject that cannot be illustrated and demonstrated. In some of these cases expert testimony is merely a yes or no answer to an hypothetical question that it may require an hour or more to read.

In forgery cases, especially when considerable writing is involved, there usually is a definite, material problem before the court that, when illustrated, interpreted and intelligently discussed, can, in many cases at least, be understood by intelligent hearers. Of course, if testimony is limited and restricted, as for example in that California digest opinion, referred to above, then it does not so much matter what kind of jury hears the testimony.

There is no doubt that the proof of forgery is made more difficult in certain states by the laws relating to wills. This is especially true in the courts of the state of Pennsylvania, where almost any scrap of paper with a genuine signature on it can be made into a will. ${ }^{17}$ This is true of brief postscripts on letters or postal cards, or a few words on a check above a genuine signature. Three or four typewritten or handwritten words before a genuine signature, or what witnesses say is a genuine signature, make a will. "All for Flo, J. Cox", is a will requiring no witnesses, no date, and it can be written anywhere on almost anything. Nor is an ordinary signature even required; the will can be signed "Father", or by initials, or by a given name.

The theory which is supposed to justify the law that no witnesses are required on a holographic will is that it is more difficult to forge a complete document than merely a signature, and this no doubt would be some protection if a considerable amount of writing was required. More than one will case has been tried in court, and the will probated, where the instrument contained only a few words in addition to the signature, and, as stated above, in one state at least, only the signature must be proved. Because of the

${ }^{17}$ See Harrison's Estate, I96 $\mathrm{Pa} .576,46$ Atl. 888 (1900) (Indorsement on envelope, signed by testator, of words "for" or "to go to" a person named, held valid will) ; Beaumont's Estate, 216 Pa. 350, 65 Atl. 799 (I907); see also Hinman v. Hinman, $283 \mathrm{~Pa}$ 29, I28 At1. 654 (1925).

It is unnecessary to have attesting witnesses in Pennsylvania. Will is properly proved by testimony of two or more competent witnesses to testator's signature; subscribing witnesses are unnecessary except in case of gifts to charities. Bilancich's Estate, 6 Dist. \& C. 743 (Pa. 1925). Cf. Succession of Lewis, I74 La. 90I, 906, I42 So. I2I (I932) : "In order to be valid an olographic will must be entirely written, dated, and signed by the hand of the testator. Civil Code, art. 1588. Proof of this must be made by the declaration of two credible witnesses." 
obvious difficulty in proving the facts many of these undoubtedly fraudulent claims are compromised, with liberal rewards to the forgers, as a contest is almost hopeless.

Finally, it is no doubt a fact that the contingent fee develops conditions that make it more difficult to prove that a forged document is in fact a forgery. Numerous legal writers say emphatically that no other one thing has so prostituted the practice of law in American courts as the contingent fee. This practice is not allowed in England or Canada. One striving for a reward of perhaps a hundred thousand dollars, or even more, is strongly tempted to find, prepare and present the kind of evidence that will lead to success. Contingent fee cases can, of course, be tried honestly but they often open the door to fraud and perjury. It is this experienced and often able advocate, who seeks in every way to prevent proof, who has made necessary the skilled and experienced special witness, or expert, who, against strenuous, ingenious and often unfair opposition, is able to counteract improper and uncontrolled advocacy and present effective proof of forgery.

Notwithstanding the many difficulties still surrounding the subject in many courts, it is a fact that at the present time hundreds of disputed document cases are tried and won that would not have been taken into the courts a few years ago when the old rules and the old prejudice were in full force. Under modern conditions in many courts the proof of a disputed document case is therefore not such a desperate undertaking as it once was, and every year it is easier to prove that forged documents are not genuine, but, as pointed out, serious difficulties still remain. The slow progress of reform is shown by the fact that only last year the great state of Texas finally passed a belated statute allowing standards of comparison to be admitted in a civil disputed document case. ${ }^{18}$

${ }^{18}$ Texas Laws I933, c. 106. Section I reads: "In the trial of any civil case, it shall be competent to give evidence of handwriting by comparison, made by experts or by the Jury. The standard of comparison offered in evidence must be proved to the satisfaction of the Judge to be genuine before allowing same to be compared with the handwriting in dispute." 